\title{
ASSESSMENT OF GENETIC VARIATION IN TURKISH LOCAL MAIZE GENOTYPES USING MULTIVARIATE DISCRIMINANT ANALYSIS
}

\author{
ÖNER, F. \\ Department of Field Crops, Agricultural Faculty, Ordu University \\ 52200 Ordu, Turkey \\ (e-mail: fatihoner38@gmail.com; phone: +90-452-226-5200; fax: +90-452-234-6632)
}

(Received 21 $1^{\text {st }}$ Sep 2017; accepted $20^{\text {th }}$ Feb 2018)

\begin{abstract}
The objective of study was to assess genetic variations among tassel and ear traits of Turkish local maize (Zea mays L.) genotypes. Seventy-nine maize germplasms consisting of three races (flint, pop and dent) from northern part of Turkey were evaluated for 16 traits (6-ear and 10-tassel) by using multivariate analysis. ANOVA revealed significant differences in ear and tassel traits. The highest positive correlations were observed between ear length and number of kernels per ear $(r=0.75$, $\mathrm{p}<0.01)$; between tassel length and number of kernels per ear $(r=0.75, p<0.01)$. The highest negative correlations were observed between mean node distance and tassel diameter $(r=-0.30, p<$ 0.01 ). Six ear traits revealed that number of ears and ear diameter multivariate correlations covered $91.6 \%$ and ear diameter, alone, $47.6 \%$ of total variation among accessions. Eight tassel traits were revealed that tassel length and tassel diameter multivariate correlation covered $88.8 \%$ and tassel diameter alone $85.1 \%$ of total variation. Totally, sixteen ear and tassel traits revealed that tassel diameter and number of flowers per main branch multivariate correlation covered $94.8 \%$ and number of flowers per main branch alone $86.8 \%$ of total variation. The races are separated into the groups, densely. Although tassel traits displayed low eigenvalue accounting for $56.8 \%$ of total variance between races, ear traits displayed very high eigenvalue accounting for $94.6 \%$ of total variance. Combined ear and tassel traits had higher eigenvalue accounting for $74.6 \%$ of total variance. Results indicated that the first and the second principal component were belonging to ear and tassel traits for Turkish maize races, respectively. The broad trait variation in maize germplasm implies large opportunities for genetic improvement of northern Turkish maize accessions.
\end{abstract}

Keywords: corn accessions, morphological traits, diversity, kernel, correlation

\section{Introduction}

Traditional cultivars and primitive landraces of maize (Zea mays L.) are invaluable treasure for humankind (Kumari et al., 2016). Turkish maize germplasm was broadly collected by Harlan (1951) in 1948. Ilarslan et al. (2001, 2002) studied these germplasm and classified their races using isozyme and multivariate analysis on agronomic and morphologic traits. They studied on three races as pop, flint and dent maize collected within the period of 1948-1952 from the whole Turkey and used 25 characters as leaf, ear, tassel and kernel traits for classification. With the study of 19 isozyme systems, they indicated that there were large genetic variation among these accessions and races without any specific clustering pattern (Ilarslan et al., 2001). In the same accessions, genetic variability was identified using multivariate analysis. Discriminant analysis showed a high eigenvalue accounting for $66.59 \%$ of total variance between races in the first canonical variable and $33.41 \%$ of total variance between races in the second canonical variable (Ilarslan et al., 2002). In most studies, it has been emphasized that phenotypic and phenological information based on morphological descriptors continues to be the first step to increase their use in corn breeding for the evaluation, identification and classification of germplasm collections (Sharma et al., 2010; Kumar et al., 2015; 
Asare et al., 2016; N'Da et al., 2015; Twumasi et al., 2017). Morphological traits and ear properties can need for future breeding progress (Badu-Apraku et al. 2014). The most commonly used parameters in the genetic diversity of corn plant are related to tassel characteristics, ear and grain characteristics (Rahman et al., 2015). The assessment of morphological characters in germplasm is important for an accurate measurement of the differences between populations for their breeding potential (Orr and Sundberg, 1994). Ear morphology also was suggested to be very useful descriptor for race classification with high heritability (Ortiz and Sevilla, 1997; Brandolini and Brandolini, 2001; Abu-Alrub et al., 2004; Sofi, 2007; Iqbal et al., 2015). Ear diameter and ratio of ear length to diameter are the most useful descriptors for maize races (AbuAlrub et al., 2004). The classification of maize accessions is a useful approach with good descriptors for maize breeding.

Northern part of Turkey, particularly, Black Sea region carries $56 \%$ of corn plantation of Turkey. Mostly, flint type maize is cultivated for animal and human consumption. The germplasm collected from the northern part of Turkey also needs a classification in terms of pop, flint and dent maize races. It was suggested that in Turkey, like other crop species, maize has a heterogeneous mixture which were studied by Anderson and Brown (1953) and Ilarslan et al. (2001, 2002). The cultivation of maize probably originated in Central America and spread to Europe via Spain, Portugal trade routes through the Ottoman traders to central Europe and the Balkans (Pavlicic and Trifunovic, 1967; Abu-Alrub et al., 2004). The spread of maize has been rapid from European regions of the Ottoman Empire by Turkish traders after its introduction in Europe (Kün, 1994; Brandolini and Brandolini, 2001). The introduction of maize to Turkey was around 1600s through Egypt and Syria. On the other hand, large-scale introduction of maize accessions was done by Turkish Agricultural Institutes after 1920s (Kün, 1994). However, there are no studies investigating the genetic variations among the maize accessions and races of the northern part of Turkey.

The objective of this research was; firstly, to assess genetic variation in tassel and ear traits as a descriptor among flint, dent and pop maize races collected from the northern part of Turkish maize varieties and second, to assess the separate effects of traits for classification in these accessions using multivariate analysis.

\section{Material and methods}

\section{Plant material}

Maize

Maize or corn is an annual outcrossing cereal in the Poaceae (Gramineae) family, reproducing excessively by seed. It is considered as one of the most productive crop species, and also the most studied and characterized crop plant. Maize is a monoecious plant growing up $4 \mathrm{~m}$ tall and forms a seasonal root systems bearing a single erect stem or stalk, made up of nodes and internodes. The leaves are arranged in two opposing rows along the stalk. The mature plant can have up to approximately 30 leaves, each consists of a sheath surrounding the stalk and an expanded blade. The corn plant produces a branched inflorescence of male flowers, the tassel and an axillary female inflorescences forming a cylindrical cob, the ears. The cobs have 16-30 rows of spikelets which develop into "kernels" when the seeds mature and long protruding styles, the corn silks. Mature kernels are typically white or yellow, but may also range 
in color from red to purple. Maize is one of the major source of starch worldwide and the kernel texture, shape and size is dependent on sugar and starch content, which differs with each variety.

Several maize types can be discerned on the basis of kernel and endosperm structure and composition. The general characteristics of the maize varieties used in this study are given below.

Dent corn: It has a large notch or depression in the kernel, when mature. Dent corn is the most commonly grown for grain and silage. Hard endosperm is present on the sides and base of the kernel, with the remainder of the kernel filled with soft starch. When the kernel starts drying, the soft starch at the top of the kernel shrinks, forming the depression or notch which it is named.

Flint corn (crusty corn): Flint corn kernels, with a very tough crust, are characterized by their hard endosperm around a small soft center. Flint maize is predominantly grown for food use.

Popcorn: It is characterized by a high proportion of hard endosperm, which is much higher than in any other kernel. The explosive capacity of the kernel, when subjected to heat, is a distinctive attribute of popcorn as well. Popcorn, produced on a small scale compared to other types, is used for making popcorn and consumed as a snack-food.

\section{Samples}

Seventy-nine maize accessions (59 flint, 16 pop and 4 dent race accessions) were collected from different locations and altitudes of northern part of Turkey $\left(41.21^{\circ} \mathrm{N}\right.$, $36.11^{\circ} \mathrm{S}$; Fig. 1) between the years 2010-2014. Characteristics of samples are given in Table 1.

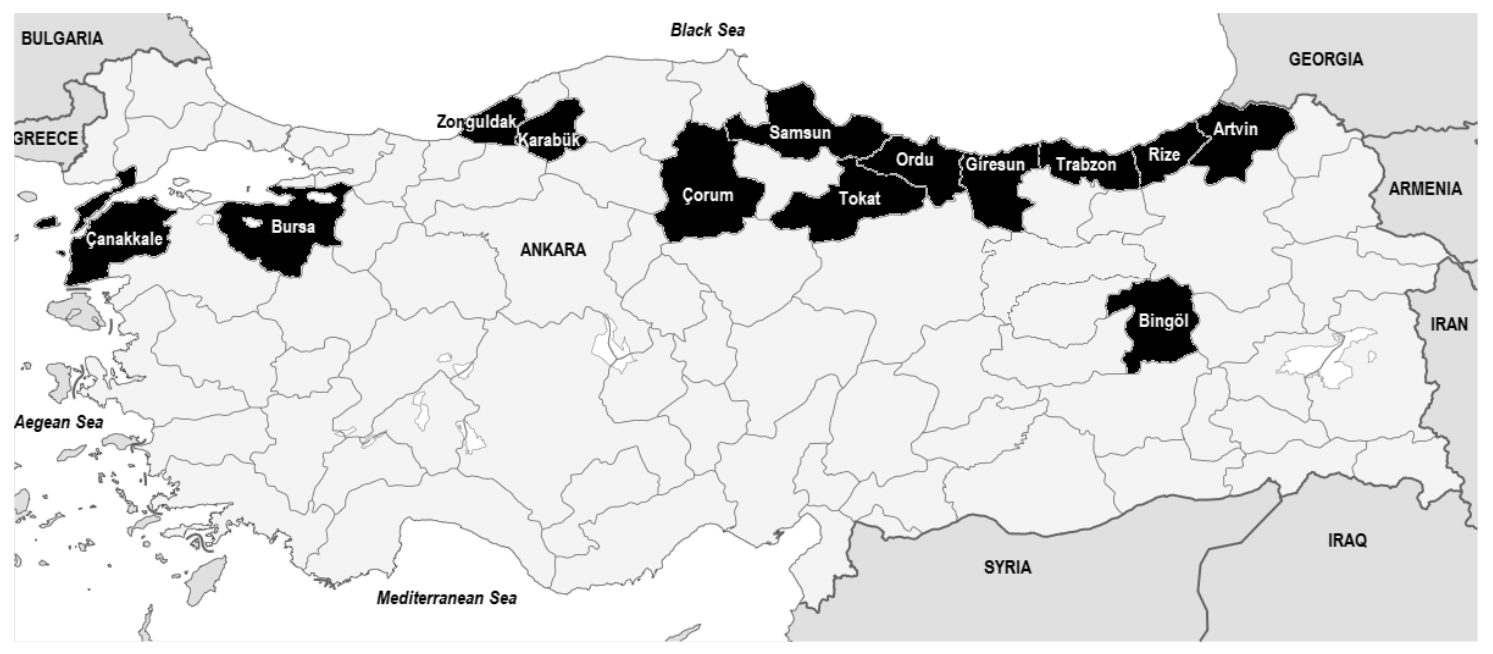

Figure 1. Origin of the accessions used in this study

Collected maize accessions were evaluated in the field during summer of 2015 at the Faculty Farm of Ordu University, Ordu-Turkey (elevation: $24 \mathrm{~m}$ ). The accessions were planted on May 15 as single-row-plots (30 plants per row in a randomized block design). The measurements were done on randomly selected 6 individuals from each row with the exception of the edge rows. Rows spacing was $0.70 \mathrm{~m}$ and on-row plant spacing was $0.20 \mathrm{~m}$. Variety classification was carried out for sixteen traits by the 
most heritable and discriminate agronomic and morphologic variables reported by several researchers (Twumasi et al., 2017; Suryanarayana et al., 2017; Sofi, 2007; Sanchez-Gonzales et al., 1992; Revilla and Tray, 1995). These variables were utilized also by Ilarslan et al. (2002) in 32 Turkish accessions. The traits were expressed in millimeters and numbers (Table 2). The data were standardized by calculating means and standard deviations for each trait across 79 accessions in accordance with Sneath and Sokal (1973).

\section{Statistical analysis $l$}

Mean values and standard errors were calculated and standardized for either tassel and ear traits or both of them to compare the effect of analysis. Data correlation matrix was constructed from the mean values and used in the multivariate discriminant function analysis to classify 65 Turkish maize accessions. Principal components were calculated from the matrix of correlations. The grouping in the collection, the clustering by un-weighted pair group method of arithmetic average (UPMGA) was computed using Euclidean dissimilarity (Table 1). The multivariate discriminant function analysis was performed using the statistical software Numerical Taxonomy and Multivariate Analysis System Version 2.1 (NTSYS-pc, Rohlf, 1993).

Table 1. Accession number, location of accessions, kernel type, and altitude of maize accessions

\begin{tabular}{|c|c|c|c|c|c|c|c|c|c|}
\hline No. & $\begin{array}{c}\text { Access. } \\
\text { no. }\end{array}$ & $\begin{array}{l}\text { Location of } \\
\text { accessions }\end{array}$ & $\begin{array}{c}\text { Kernel } \\
\text { type }\end{array}$ & Altitude & No. & $\begin{array}{c}\text { Access. } \\
\text { no. }\end{array}$ & $\begin{array}{l}\text { Location of } \\
\text { accessions }\end{array}$ & $\begin{array}{l}\text { Kernel } \\
\text { type }\end{array}$ & Altitude \\
\hline & Black Sea & & & & & & & & \\
\hline & Region & & & & & & & & \\
\hline 1 & 3 & Samsun & $\mathrm{F}$ & 32 & 45 & 70 & Samsun & $\mathrm{F}$ & 46 \\
\hline 2 & 4 & Samsun & $\mathrm{F}$ & 45 & 46 & 71 & Samsun & $\mathrm{F}$ & 47 \\
\hline 3 & 8 & Samsun & $\mathrm{F}$ & 30 & 47 & 72 & Samsun & $\mathrm{F}$ & 51 \\
\hline 4 & 12 & Samsun & $\mathrm{F}$ & 48 & 48 & 73 & Samsun & $\mathrm{F}$ & 52 \\
\hline 5 & 16 & Samsun & $\mathrm{F}$ & 23 & 49 & 74 & Samsun & $\mathrm{F}$ & 55 \\
\hline 6 & 17 & Samsun & $\mathrm{F}$ & 55 & 50 & 75 & Ordu & $\mathrm{F}$ & 234 \\
\hline 7 & 29 & Tokat & $\mathrm{F}$ & 520 & 51 & 76 & Samsun & $\mathrm{D}$ & 55 \\
\hline 8 & 28 & Tokat & $\mathrm{F}$ & 618 & 52 & 77 & Ordu & $\mathrm{D}$ & 229 \\
\hline 9 & 27 & Tokat & $\mathrm{F}$ & 581 & 53 & 78 & Ordu & $\mathrm{D}$ & 244 \\
\hline 10 & 25 & Trabzon & $\mathrm{F}$ & 420 & 54 & 79 & Samsun & $\mathrm{D}$ & 50 \\
\hline 11 & 23 & Trabzon & $\mathrm{F}$ & 250 & 55 & 80 & Zonguldak & $\mathrm{F}$ & 500 \\
\hline 12 & 22 & Rize & $\mathrm{F}$ & 280 & 56 & 81 & Zonguldak & $\mathrm{F}$ & 521 \\
\hline 13 & 20 & Samsun & $\mathrm{F}$ & 35 & 57 & 84 & Artvin & $\mathrm{F}$ & 1500 \\
\hline 14 & 21 & Rize & $\mathrm{F}$ & 678 & 58 & 54 & Samsun & $\mathrm{F}$ & 55 \\
\hline 15 & 19 & Samsun & $\mathrm{F}$ & 39 & 59 & 48 & Giresun & $\mathrm{F}$ & 1000 \\
\hline 16 & 31 & Çorum & $\mathrm{F}$ & 467 & 60 & 53 & Trabzon & $\mathrm{F}$ & 155 \\
\hline 17 & 32 & Ordu & $\mathrm{F}$ & 125 & 61 & 82 & Karabük & $\mathrm{P}$ & 800 \\
\hline 18 & 41 & Karabük & $\mathrm{F}$ & 345 & 62 & 83 & Karabük & $\mathrm{P}$ & 800 \\
\hline 19 & 86 & Samsun & $\mathrm{F}$ & 605 & 63 & 6 & Samsun & $\mathrm{P}$ & 67 \\
\hline 20 & 87 & Giresun & $\mathrm{F}$ & 818 & 64 & 11 & Samsun & $\mathrm{P}$ & 56 \\
\hline 21 & 88 & Samsun & $\mathrm{F}$ & 35 & 65 & 14 & Samsun & $\mathrm{P}$ & 34 \\
\hline 22 & 89 & Samsun & $\mathrm{F}$ & 35 & 66 & 15 & Samsun & $\mathrm{P}$ & 34 \\
\hline
\end{tabular}




\begin{tabular}{|c|c|c|c|c|c|c|c|c|c|}
\hline 23 & 90 & Samsun & $\mathrm{F}$ & 35 & 67 & 26 & Tokat & $\mathrm{P}$ & 903 \\
\hline 24 & 43 & Artvin & $\mathrm{F}$ & 1210 & 68 & 24 & Trabzon & $\mathrm{P}$ & 874 \\
\hline 25 & 46 & Ordu & $\mathrm{F}$ & 365 & 69 & 30 & Çorum & $\mathrm{P}$ & 250 \\
\hline 26 & 49 & Samsun & $\mathrm{F}$ & 68 & 70 & 47 & Trabzon & $\mathrm{P}$ & 200 \\
\hline 27 & 50 & Karabük & $\mathrm{F}$ & 350 & & Marmara & & & \\
\hline 28 & 51 & Samsun & $\mathrm{F}$ & 35 & & Region & & & \\
\hline 29 & 52 & Samsun & $\mathrm{F}$ & 44 & 71 & 35 & Çanakkale & $\mathrm{F}$ & 600 \\
\hline 30 & 55 & Trabzon & $\mathrm{F}$ & 235 & 72 & 36 & Çanakkale & $\mathrm{F}$ & 600 \\
\hline 31 & 56 & Ordu & $\mathrm{F}$ & 130 & 73 & 39 & Çanakkale & $\mathrm{P}$ & 600 \\
\hline 32 & 57 & Samsun & $\mathrm{F}$ & 46 & 74 & 40 & Çanakkale & $\mathrm{F}$ & 345 \\
\hline 33 & 58 & Samsun Samsun & $\mathrm{F}$ & 43 & 75 & 37 & Çanakkale & $\mathrm{P}$ & 600 \\
\hline 34 & 59 & Samsun & $\mathrm{F}$ & 120 & 76 & 38 & Çanakkale & $\mathrm{P}$ & 600 \\
\hline 35 & 60 & Trabzon & $\mathrm{F}$ & 112 & 77 & 42 & Bursa & $\mathrm{P}$ & 450 \\
\hline 36 & 61 & Trabzon Samsun & $\mathrm{F}$ & 150 & 78 & 34 & Çanakkale & $\mathrm{P}$ & 678 \\
\hline 37 & 62 & Trabzon & $\mathrm{F}$ & 165 & & East & & & \\
\hline 38 & 63 & Samsun & $\mathrm{F}$ & 29 & & Anatolia & & & \\
\hline 39 & 64 & Samsun & $\mathrm{F}$ & 163 & & Region & & & \\
\hline 40 & 65 & Samsun & $\mathrm{F}$ & 45 & 79 & 85 & Bingöl & $\mathrm{P}$ & 800 \\
\hline 41 & 66 & Ordu & $\mathrm{F}$ & 54 & & & & & \\
\hline 42 & 67 & Samsun & $\mathrm{F}$ & 47 & & & & & \\
\hline 43 & 68 & & $\mathrm{~F}$ & 243 & & & & & \\
\hline 44 & 69 & & $\mathrm{~F}$ & 39 & & & & & \\
\hline
\end{tabular}

Table 2. Ear and tassel trait means and standard deviation for maize races; flint, pop and dent

\begin{tabular}{c|c|c|c|c}
\hline Trait/Varieties & $\begin{array}{c}\text { Flint(59) } \\
\text { mean } \pm \text { SD }\end{array}$ & $\begin{array}{c}\text { Pop(16) } \\
\text { mean } \pm \text { SD }\end{array}$ & $\begin{array}{c}\text { Dent(4) } \\
\text { mean } \pm \text { SD }\end{array}$ & F $^{\mathbf{1}}$ \\
\hline Ear Traits & & & & \\
Ear number (number) EN & $1.13 \pm 0.21$ & $1.10 \pm 0.10$ & $1.12 \pm 0.19$ & $* *$ \\
Ear diameter (cm) ED & $20.79 \pm 3.10$ & $18.01 \pm 2.30$ & $20.24 \pm 3.09$ & $* *$ \\
Ear length (cm) EL & $16.10 \pm 3.77$ & $14.25 \pm 2.55$ & $18.00 \pm 3.55$ & $*$ \\
Ear row number (number) ER & $11.11 \pm 2.82$ & $14.37 \pm 2.55$ & $11.79 \pm 3.01$ & $* *$ \\
Ear kernel number (number) EK & $29.61 \pm 7.41$ & $33.31 \pm 8.70$ & $30.63 \pm 7.90$ & - \\
Ear height (cm) EH & $88.71 \pm 35.60$ & $81.87 \pm 29.31$ & $131.25 \pm 27.8$ & $* *$ \\
Tassel Traits & & & & \\
Tassel length (cm) TL & $38.457 \pm 7.518$ & $36.00 \pm 4.83$ & $46.75 \pm 4.72$ & $* *$ \\
Number of branch (number) NB & $14.64 \pm 4.59$ & $17.06 \pm 5.01$ & $15.29 \pm 4.67$ & - \\
Tassel weight (g) TW & $16.52 \pm 9.26$ & $16.96 \pm 7.72$ & $17.01 \pm 9.40$ & - \\
Number of flower (number) NF & $720 \pm 371.05$ & $848.6 \pm 228.3$ & $751.2 \pm 343.7$ & $* *$ \\
Tassel diameter (cm) TD & $4.66 \pm 0.68$ & $4.63 \pm 0.84$ & $4.69 \pm 0.71$ & $* *$ \\
Branch length (cm) BL & $131.55 \pm 42.47$ & $165.43 \pm 54.0$ & $138.02 \pm 45.8$ & $* *$ \\
Main branch flower number (number) NBFM & $19.14 \pm 4.54$ & $17.44 \pm 2.88$ & $18.90 \pm 4.29$ & $* *$ \\
Number of flower per branch NFB & $48.50 \pm 11.40$ & $52.87 \pm 10.46$ & $49.11 \pm 11.50$ & $* *$ \\
First branch angle (degree) FNA & $64.57 \pm 9.70$ & $62.62 \pm 6.90$ & $64.24 \pm 9.14$ & $* *$ \\
Mean distance between nodes MDB & $0.79 \pm 0.20$ & $0.71 \pm 0.18$ & $0.77 \pm 0.21$ & $*$ \\
\hline
\end{tabular}

$* \mathrm{p}<0.05, * * \mathrm{p}<0.01$ 


\section{Results and discussion}

\section{Analysis of maize races}

The ear and tassel traits of maize races, except for number of kernels per ear, tassel weight and number of branch per tassel, revealed significant relationships. Particularly, studied traits showed significantly different values in different races (Table 2).

Some results were related to Turkish accessions collected from the whole Turkey studied by Ilarslan et al. (2002), because they are highly heritable traits (SanchezGonzales, 1989; Sanchez-Gonzales et al., 1993; Revilla and Tracy, 1995; Iqbal et al., 2015). The high variance within varieties indicates that accessions have already been utilized by farmers for many years. Most of the accessions came from the coastal regions where growing seasons are longer than inland regions. The preference of flint and pop maize races comes from the intense use of them for either human or animal food in the coastal region and timely-earning for other alternative plants for winter.

The correlation between inter and intra-ear and tassel traits was significant. For example, positive correlations were observed among number of ear, ear diameter, number of kernels per ear, ear height, tassel length, number of flower per tassel, tassel diameter, number of flower per main branch, branch angel. The highest positive correlations were observed between ear length and number of kernels per ear; between tassel length and number of ears. The highest negative correlations were observed between mean node distance and tassel diameter (Table 3).

Table 3. Correlation coefficients between ear and tassel traits

\begin{tabular}{|c|c|c|c|c|c|c|c|c|c|c|c|c|c|c|c|}
\hline & EN & ED & EL & ER & EK & EH & TL & NB & TW & NF & TD & NBFM & BL & NFB & FNA \\
\hline ED & $0.42 * *$ & 1.00 & & & & & & & & & & & & & \\
\hline EL & -0.12 & $0.24 *$ & 1.00 & & & & & & & & & & & & \\
\hline ER & $0.44 * *$ & $0.41 * *$ & 0.11 & 1.00 & & & & & & & & & & & \\
\hline EK & -0.07 & 0.08 & $0.75 * *$ & $0.24 *$ & 1.00 & & & & & & & & & & \\
\hline EH & $0.35^{* *}$ & $0.27 * *$ & $0.36 * *$ & 0.06 & $0.21 *$ & 1.00 & & & & & & & & & \\
\hline TL & $0.75^{* *}$ & $0.47 * *$ & 0.11 & $0.37 * *$ & 0.02 & $0.53 * *$ & 1.00 & & & & & & & & \\
\hline NB & 0.11 & -0.07 & -0.01 & 0.08 & 0.11 & 0.06 & 0.01 & 1.00 & & & & & & & \\
\hline TW & 0.13 & -0.12 & -0.04 & -0.09 & 0.08 & $0.36 * *$ & $0.21 *$ & 0.15 & 1.00 & & & & & & \\
\hline NF & $0.49 * *$ & $0.24 *$ & 0.06 & $0.33 * *$ & 0.11 & $0.22 *$ & $0.50 * *$ & $0.32 * *$ & $0.43 * *$ & 1.00 & & & & & \\
\hline TD & $-0.25^{*}$ & 0.10 & $0.31 * *$ & -0.04 & $0.22 *$ & 0.10 & -0.09 & $0.23 *$ & -0.15 & -0.06 & 1.00 & & & & \\
\hline NBFM & $0.24 *$ & $0.43 * *$ & $0.24 *$ & $0.20 *$ & -0.01 & $0.36 * *$ & $0.46^{* * *}$ & -0.07 & -0.08 & 0.14 & $0.35^{* *}$ & 1.00 & & & \\
\hline BL & $0.52 * *$ & 0.13 & $-0.28 * *$ & $0.22 *$ & -0.08 & 0.07 & $0.36^{* *}$ & 0.01 & $0.26 * *$ & $0.47 * *$ & $-0.38 * *$ & -0.11 & 1.00 & & \\
\hline NFB & 0.06 & 0.09 & -0.53 & 0.12 & -0.05 & -0.16 & -0.02 & 0.03 & 0.00 & $0.22 *$ & -0.10 & -0.14 & $0.21 *$ & 1.00 & \\
\hline FNA & $0.56^{* *}$ & $0.35 * *$ & 0.12 & $0.39 * *$ & 0.17 & $0.25 *$ & $0.56^{* *}$ & 0.03 & $0.25^{*}$ & $0.46^{* *}$ & -0.16 & 0.13 & $0.34 * *$ & $0.26 * *$ & 1.00 \\
\hline MDB & -0.03 & -0.08 & -0.09 & -0.44 & 0.04 & $-0.20 *$ & $-0.22 *$ & -0.04 & -0.08 & -0.18 & $-0.28 *$ & $-0.30 * *$ & 0.01 & -0.16 & 0.05 \\
\hline
\end{tabular}

$* \mathrm{p}<0.05, * * \mathrm{p}<0.01$

Turkish farmers usually grow the plants with the seeds selected from previous plants with better growth forms, morphologic and agronomic characteristics. Used seeds by farmers in the following year are limited to randomly bulked seed collections of previous year. Maize is an out-breeder and there is no isolation distance for maize plantations. Flint and pop maize plants are grown as mixed in the same fields in most of the farms. 
On the other hand, exchange of seeds between villages is limited with the easy and cheap facilities within the village. The seeds used in this study were collected from high and low altitude farms. However, low altitude farm owners prefer hybrid plants which can allow gene flow between growth plantations until $200 \mathrm{~m}$ in plain areas (Luna et al., 2001).

The Fisher's linear discriminant functions and Classification Function Coefficients showed that the most important ear traits were number of ears, ear diameter, number of kernels per ear and ear height while tassel traits were tassel length, tassel diameter, number of flowers per main branch, branch angel, and mean node distance, respectively (Table 4). The most preferable traits were found to be number of ears and tassel length.

Table 4. Eigenvalue, multivariate correlation of ear and tassel traits for races

\begin{tabular}{c|c|c|c|c|c|c|c|c}
\hline Function & $\begin{array}{c}\text { Eigenvalue } \\
\text { (ear) }\end{array}$ & $\begin{array}{c}\text { \% of } \\
\text { variance }\end{array}$ & $\begin{array}{c}\text { Cumulative } \\
\text { \% }\end{array}$ & $\begin{array}{c}\text { Canonical } \\
\text { correlation }\end{array}$ & $\begin{array}{c}\text { Eigenvalue } \\
\text { (tassel) }\end{array}$ & $\begin{array}{c}\text { \% of } \\
\text { variance }\end{array}$ & $\begin{array}{c}\text { Cumulative } \\
\text { \% }\end{array}$ & $\begin{array}{c}\text { Canonical } \\
\text { correlation }\end{array}$ \\
\hline 1 & 5.179 & 94.6 & 94.6 & 0.916 & 3.444 & 56.8 & 56.8 & 0.880 \\
\hline 2 & 0.294 & 5.4 & 100.0 & 0.476 & 2.617 & 43.2 & 100.0 & 0.851 \\
\hline
\end{tabular}

Six ear traits revealed that first two multivariate correlations covered $91.6 \%$ and second, $47.6 \%$ of total variation, and eight tassel traits were revealed that first two multivariate correlations covered $88.8 \%$ and second, $85.1 \%$ of total variation among accessions.

The first multivariate discriminant function (Fig. $2 a$ and $b$ ) had high eigenvalue with $94.6 \%$ of total variance between varieties for ear trait and $56.8 \%$ of total variance between varieties for tassel trait belonged to flint and pop maize accessions while the second multivariate variable belonged to flint and dent maize accessions for ear traits (Table 5).

Table 5. Classification of function coefficients for ear traits

\begin{tabular}{c|c|c|c|c|c|c|c}
\hline \multirow{2}{*}{ Ear traits } & \multicolumn{3}{|c|}{ Races } & \multirow{2}{*}{ Tassel traits } & \multicolumn{3}{|c}{ Races } \\
\cline { 2 - 4 } & $\mathbf{1}$ & $\mathbf{2}$ & $\mathbf{3}$ & & $\mathbf{1}$ & $\mathbf{2}$ & $\mathbf{3}$ \\
\hline EN & 0.071 & 0.124 & 0.122 & TL & 0.062 & 0.095 & 0.092 \\
ED & 0.064 & 0.076 & 0.091 & TD & 0.062 & 0.046 & 0.070 \\
EK & 0.071 & 0.096 & 0.095 & NBFM & 0.023 & 0.019 & 0.107 \\
EH & 0.024 & 0.018 & 0.045 & FNA & 0.080 & 0.105 & 0.097 \\
- & - & - & - & NBF & 0.030 & 0.044 & -0.006 \\
\hline (Constant) & -59.488 & -117.143 & -137.964 & (Constant) & -75.475 & -111.050 & -153.13 \\
\hline
\end{tabular}

These results showed that north Turkish maize accessions were classified for their racial characteristics which were grouped as flint, pop and dent maize accessions from the angle of race with tassel and ear traits by multivariate discriminant function analysis. In previous studies, it was revealed (Ilarslan et al., 2002) that the results were quite similar each other for classification of maize varieties. On the other hand, significant relationships were not observed between pop and flint maize varieties studied by enzyme polymorphism (Ilarslan et al., 2001) but, the same study suggested that there can be a gene flow between flint and pop maize varieties. Grobman et al. 
(1961) and Iqbal et al. (2015) studied maize accessions assigned to the races on the basis of ear traits as descriptor. In both study, tassel and ear traits were used as a descriptor of maize accessions.

The cross sections of centroid of multivariate discriminant function in Figure $2 a$ and $b$ showed the center of accessions that display a good value for races. In Figure $2 a$, the distribution of accessions for ear traits showed a grouping but not dense, whereas tassel traits showed more clear distributions of accessions (Fig. 2b).

Figure $2 a$ gives information on the classification of accessions that seem to be mixture of different races between dent and pop type maize accessions analyzed by ear traits. Whereas Figure $2 b$ looks like that there was a mixture of between flint and pop maize varieties. These two results explain that the importance of trait used in the analysis was not because of pollen exchanges.

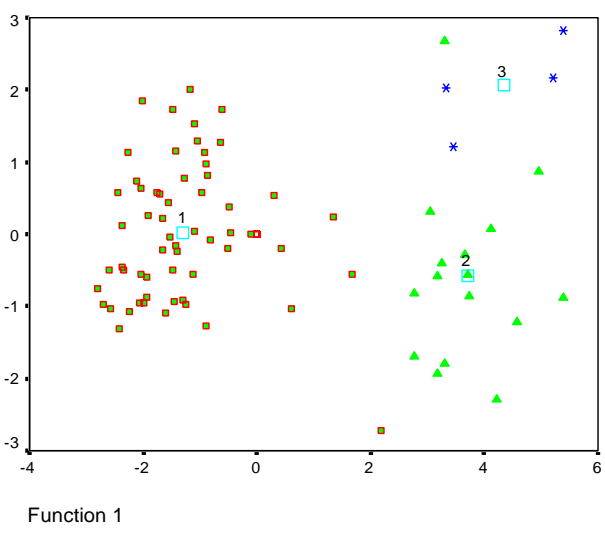

$\boldsymbol{a}$

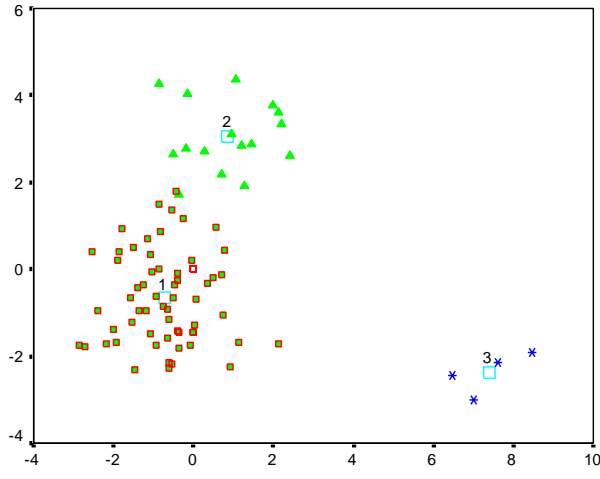

Function 1

$\boldsymbol{b}$

Figure 2. The grouping of Turkish maize accessions based on multivariate discriminant function analysis for (a) ear and (b) tassel traits. Maize varieties were displayed as $F(1), P(2)$, and $D(3)$

\section{Classification of germplasms}

The Fisher's linear discriminant functions and Classification Function Coefficients showed that the most important traits in the classification were tassel diameter, number of flowers per main branch, branch angel, number of ears and number of kernels per ear, respectively. Their Classification Function Coefficients are given based on races in Table 6. The most preferable trait was found to be tassel diameter for further studies.

Table 6. Classification of function coefficients for ear and tassel traits

\begin{tabular}{c|c|c|c}
\hline \multirow{2}{*}{} & \multicolumn{3}{|c}{ Races } \\
\cline { 2 - 4 } & $\mathbf{1}$ & $\mathbf{2}$ & $\mathbf{3}$ \\
\hline TD & 0.048 & 0.025 & 0.050 \\
NBFM & 0.063 & 0.083 & 0.175 \\
FNA & 0.103 & 0.140 & 0.133 \\
NBF & 0.023 & 0.034 & -0.014 \\
EN & 0.098 & 0.159 & 0.177 \\
ER & 0.092 & 0.137 & 0.127 \\
\hline (Constant) & -112.232 & -203.531 & -263.767 \\
\hline
\end{tabular}


Totally, sixteen ear and tassel traits were subjected to multivariate discriminant function analysis and the results revealed that first two multivariate correlations covered 94.8\% and second, $86.8 \%$ of total variation among accessions. The first multivariate discriminant function (Fig. 2) had high eigenvalue (74.6\% of total variance between varieties) belonged to flint and pop maize accessions while the second multivariate variable belonged to flint and dent maize accessions (Table 7).

Table 7. Eigenvalue, multivariate correlation of ear and tassel traits for races

\begin{tabular}{c|c|c|c|c}
\hline Function & Eigenvalue & \% of variance & Cumulative \% & Canonical correlation \\
\hline 1 & 8.795 & 74.6 & 74.6 & 0.948 \\
2 & 2.992 & 25.4 & 100.0 & 0.866 \\
\hline
\end{tabular}

These results showed that north Turkish maize accessions can be classified for their racial characteristics grouping as flint, pop and dent maize accessions from the angle of seed collection and ear traits by multivariate discriminant function analysis. The cross sections of centroid of multivariate discriminant function are shown in Figure 3.

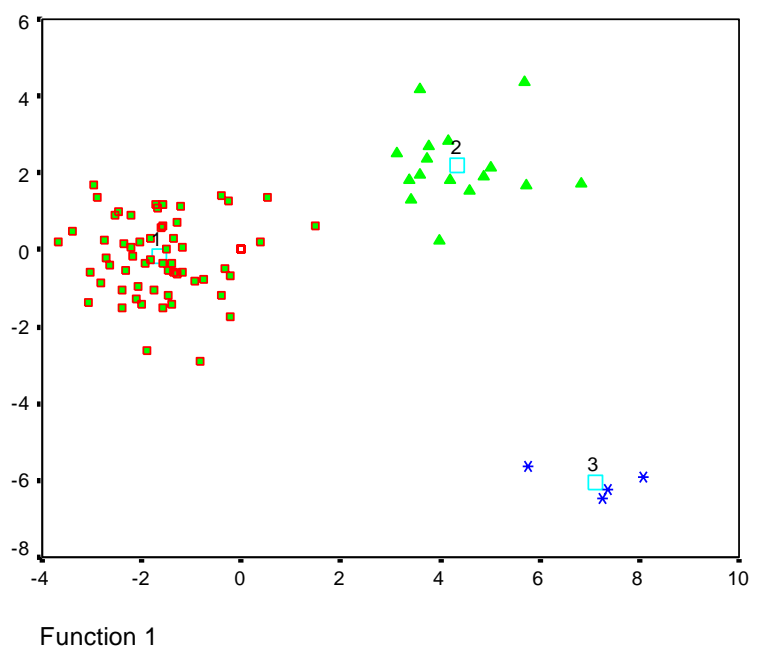

Figure 3. The grouping of Turkish maize accessions based on multivariate discriminant function analysis for ear and tassel traits. Maize varieties were displayed as $F(1), P(2)$ and $D(3)$

Previous studies revealed that the results were quite similar each other for classification of maize varieties (Ilarslan et al., 2002). On the other hand, any relationships were not observed between pop and flint maize varieties studied by enzyme polymorphism and the accessions were not classified in cluster analysis with respect to location, many small clusters formed (Ilarslan et al., 2001) but, the same study suggested that there can be a gene flow between flint and pop maize varieties. In this study, there was a good clustering between accessions for maize races. It was observed that the selection and amount of descriptor were important for classification of germplasm. The dendogram classified the accessions based on their races as seen in Figure 4. 
The clustering did not show any grouping for location. The classification of accessions implies that the accessions were conserved by the farmers in the growth plantations. It should be kept in mind that most of the accessions belonged to flint type.

Tassel traits with high heritability can be used as descriptors (Ortiz et al., 1997; Iqbal et al., 2015). Also, ear traits are important for classification and characterization of germplasms. The study showed that maize accessions collected from north of Turkey in 2010-2014 maintain considerable genetic variation in ear and tassel traits at the level of either varieties. Turkish seed collections are available in NCRPIS, Ames, USA collected in 1948-1952, which is set up test plantations to increase the seeds and maintain the genetic resources for further exploration in maize breeding programs. Ilarslan et al. (2002) studied on these accessions (32 accessions) for the genetic composition of maize genetic resources of Turkey. When Turkish accessions between 1948-1952 and 2015 were compared, it seems that there was a higher variation between research years (68\% for 1948-1952 and $74.6 \%$ for 2015). The reason of this may come from the study area which is the northern part of Turkey and most of the genotypes belonged to flint type accessions (59). In addition to this suggestion, introduction of high yield genetic lines may increase the genetic variation.

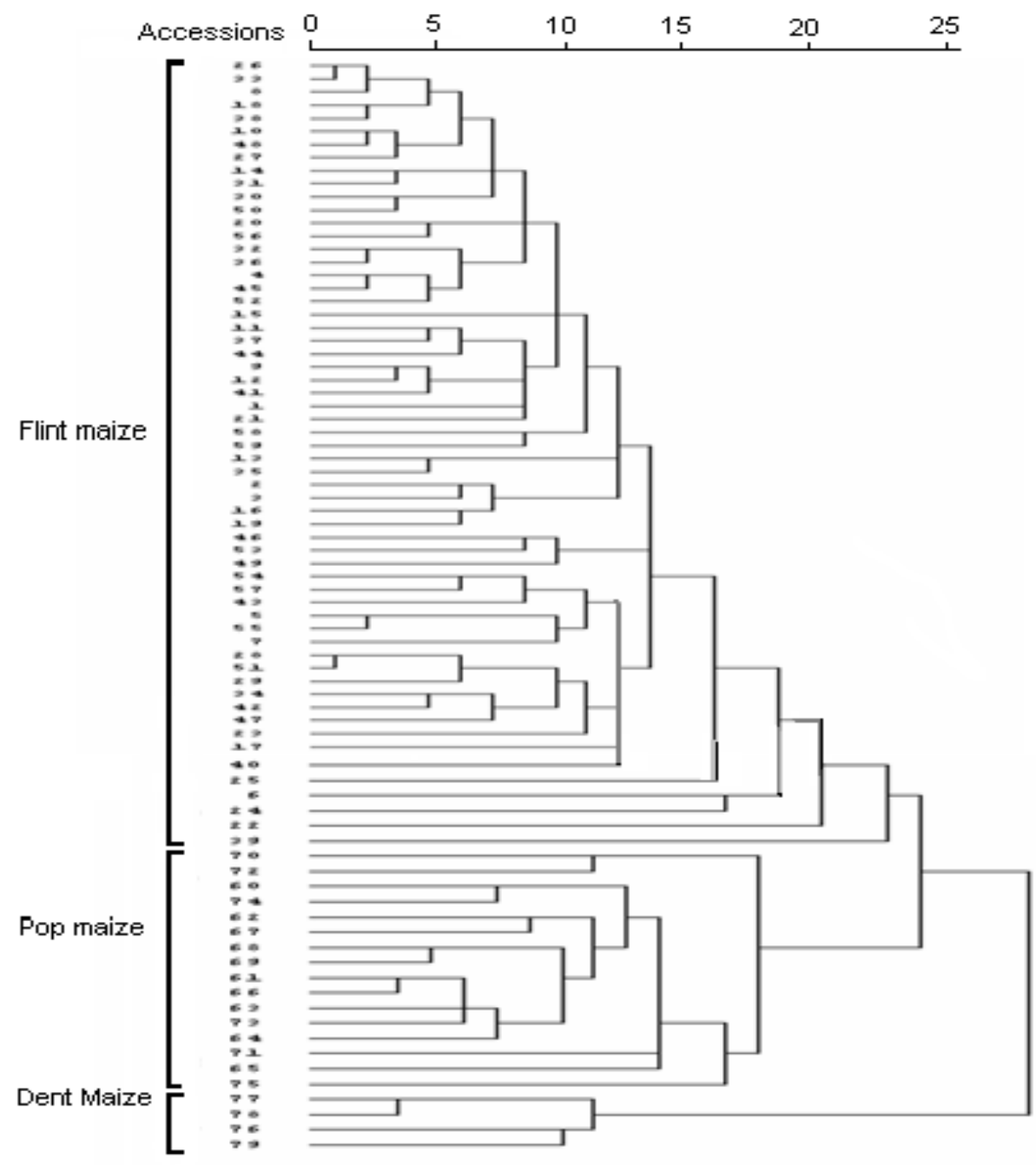

Figure 4. The clustering by unweighted pair group method of arithmetic average showing the clusters of Turkish accessions of maize collected the north of Turkey 


\section{Conclusions}

This study displays an informative knowledge of populations between years and preferable traits for selection to understand the background of accessions of following generations with high adaptive capacity for the region and selection effect of farmers for conservation of maize genetic resources. However, the application of analysis showed a value related to the number of trait. The increasing number of heritable traits gives more effective classification of genotypes. As seen in Figure 3, the races were separated into the groups, densely. In conclusion, ear traits are the best descriptors for classification of germplasms and tassel traits are not reliable descriptors alone. Likewise, there were not any overlapping accessions among the races. It was considered that the selection and amount of descriptor are important for classification of germplasm. The broad trait variation in the maize germplasm implies large opportunities for genetic improvement of northern Turkish maize accessions.

\section{REFERENCES}

[1] Abu-Alrub, I., Christiansen, S., Madsen, Sevilla, R., Ortiz, R. (2004): Assessing tassel, kernel and ear variation in Peruvian highland maize. - Plant Genetic Resources Newsletter 137: 34-41.

[2] Anderson, E., Brown, W. L. (1953): The popcorns of Turkey. - Annals of the Missouri Botanical Garden 40: 33-49.

[3] Asare, S., Tetteh, A. Y., Twumasi, P., Adabe, K. B., Akromah, R. A. (2016): Genetic diversity in lowland, midaltude and highland African maize landraces by morphological trait evaluation. - African Journal of Plant Science 10(11): 246-257.

[4] Badu-Apraku, B., Fakorede, M. A. B., Oyekunle, M. (2014): Agronomic traits associated with genetic gains in maize yield during three breeding eras in West Africa. - Maydica 59: 49-57.

[5] Brandolini, A., Brandolini, A. (2001): Classification of Italian maize (Zea mays L.) germplasm. - Plant Genetic Resources Newsletter 126: 1-11.

[6] Grobman, A., Salhuana, W., Sevilla, R., Mangelsdorf, E. (1961): Races of Maize in Peru; Their Origin, Evolution and Classification. - National Academy of Science-National Research Council (Pub. 915), Washington DC.

[7] Harlan, J. R. (1951): Anatomy of gene centers. - The American Naturalist 85(821): 97103.

[8] Ilarslan, R., Kaya, Z., Kandemir, I., Bretting, P. K. (2001): Genetic variability among Turkish pop, flint and dent maize (Zea mays L. spp. mays) varieties: Morphological and agronomical traits. - Euphytica 128: 173-182.

[9] Ilarslan, R., Kaya, Z., Kandemir, I., Bretting, P. K. (2002): Genetic variability among Turkish pop, flint and dent maize (Zea mays L. spp. mays) varieties: Enzyme polymorphism. - Euphytica 122: 171-179.

[10] Iqbal, J., ShinWari, Z. K., Rabbani, M. A. (2015): Maize (Zea mays L.) germplasm agromorphological characterization based on descriptive, cluster and principal component analysis. - Pakistan Journal of Botany 47(SI): 255-264.

[11] Kumar, A., Kumari, J., Rana, J. C., Chaudhary, D. P., Kumar, R., Singh, H., Singh, T. P., Dutta, M. (2015) Diversity among maize landraces in North West Himalayan region of India assessed by agro-morphological and quality traits. - Indian Journal of Genetics and Plant Breeding 75(2): 188-195.

[12] Kumari, J., Kumar, A., Bhatt, K. C., Mishra, A. K., Singh, T. P. (2016): Characterization of maize collections from Nagalang State of North Eastern Himalayan Region. - Plant Gene and Trait 7(12): 1-7. 
[13] Kün, E. (1994): Tahillar II (Sicak Iklim Tahillari). - Ankara Üniversitesi Ziraat Fakültesi yayinlari 1360: 141-206.

[14] Luna, S. V., Figueroa, J. M., Baltazar, B. M., Gomez, L. R., Townsend, R., Schoper, J. B. (2001): Maize pollen longevity and distance isolation requirements for effective pollen control. - Crop Science 41: 1551-1557.

[15] N'Da, H. A., Akanvou, L., Bi-Zoro, A. I., Kouakou, C. K. (2015): Phenotypic diversity of farmer's maize (Zea mays L) varieties in Cote d'lvoire. - Maydica 60(13): 1-7.

[16] Orr, A., Sundberg, M. D. (1994): Inflorescence development in a perennial teosinte: Zea perennis (Poaceae). - American Journal of Botany 81: 598-608.

[17] Ortiz, R., Sevilla, R. (1997): Quantitative descriptors for classification and characterization of highland Peruvian maize. - Plant Genetic Resources Newsletter 110: 49-52.

[18] Pavlicic, J., Trifunovic, V. (1967): A study of some important ecological corn types in Yugoslavia and their classification. - Journal of Scientific Agricultural Research 19: 4262.

[19] Rahman, S., Mia, M. M., Quddus, T., Hassan, L., Haque, A. M. (2015): Assessing genetic diversity of maize (Zea mays L.) genotypes for agronomic traits. - Research in Agriculture, Livestock and Fisheries 2(1): 53-61.

[20] Revilla, P.. Tracy, J. (1995): Morphological characterization and classification of openpollinated sweet maize cultivars. - Journal of American Society, Horticultural Science 120: $112-118$.

[21] Rohlf, F. J. (1993): NTSYS-pc. Numerical Analysis and Multivariate Analysis System Version 1.7. - Applied Biostatistics, Inc., New York, USA.

[22] Sanchez-Gonzalez, J. J. (1989): Relationships among the Mexican Varieties of Maize. $\mathrm{Ph}$. D. Dissertation, North Carolina State University, Raleigh.

[23] Sanchez-Gonzalez, J. J., Goodman, M. M. (1992): Relationships among the Mexican and some north American and south American varieties of maize. - Maydica 37: 41-51.

[24] Sanchez-Gonzalez, J. J. Goodman, M. M., Rawlings, J. O. (1993): Appropriate characters for racial classification in maize. - Economic Botany 47: 44-59.

[25] Sharma, L., Prasanna, B. M., Ramesh, B. (2010): Analysis of phenotypic and microsatellite-based diversity of maize landraces in India, especially from the North East Himalayan region. - Genetica 138(6): 619-631.

[26] Sneath, P., Sokal, R. R. (1973): Numerical Taxonomy. - W. H. Freeman and Company, San Francisco.

[27] Sofi, A. P. (2007): Genetic Analysis of tassel and ear characters in maize (Zea mays L.) using triple test cross. - Asian Journal of Plant Sciences 6(5): 881-883.

[28] Suryanarayana, L., Sekhar, M. R., Babu, D. R., Ramana, A. V., Rao, V. S. (2017): Cluster and principal component analysis in maize. - International Journal of Current Microbiology and Applied Sciences 6(7): 354-359.

[29] Twumasi, P., Tetteh, A. Y., Adabe, K. B., Asare, S., Akromah, R. A. (2017): Morphological diversity and relationships among the IPGRI maize (Zea mays L.) landraces held in IITA. - Maydica 2017 62(35): 1-9. 